\title{
SUSTAINABILITY REPORTING AND FIRM PERFORMANCE
}

\author{
DOI: 10.17261/Pressacademia.2019.1071 \\ PAP- V.9-2019(18)-p.81-84
}

\section{Idil Kaya ${ }^{1}$, Destan Halit Akbulut ${ }^{2}$}

${ }^{1}$ Galatasaray University, Ortakoy Campus, Istanbul, Turkey. ikaya@gsu.edu.tr, ORCID: 0000-0002-9171-5989

${ }^{2}$ Galatasaray University, Ortakoy Campus, Istanbul, Turkey.

dhakbulut@gsu.edu.tr, ORCID: 0000-0002-0705-9553

To cite this document

Kaya, I., Akbulut, D.H. (2019). Sustainability reporting and firm performance. PressAcademia Procedia (PAP), V.9, p.81-84

Permemant link to this document: http://doi.org/10.17261/Pressacademia.2019.1071

Copyright: Published by PressAcademia and limited licenced re-use rights only.

\begin{abstract}
Purpose- The aim of this paper is to examine sustainability reporting and its relation with firm performance. We investigate whether such reporting practices improve the firm value while enhancing its profitability and the financial leverage impact on sustainability reporting in the automotive industry.

Methodology- The paper's design is based on panel data logistic regression analysis of 155 automotive firms from 20 different countries, between 2010-2018 years. We use financial data such as Tobin's Q ratio of the public companies as well as firm size, financial leverage ratio and return on assets to measure the firm performance and we work with GRI's reports on GRI Sustainability Disclosure Database.

Findings- We find similar results with some prior literature explaining that sustainability reporting has a significant positive relation between firm size and negative relation with financial leverage.

Conclusion- The study provides understandings on the relation of firm performance, firm size, financial leverage, and sustainability reporting. The findings of study indicate a positive significant relationship between firm size and SR, and a negative significant relationship between financial leverage and sustainability reporting in the automotive industry.
\end{abstract}

Keywords: Sustainability reporting, CSR reporting, firm performance, social and environmental reporting JEL Codes: M40, M49, Q56

\section{INTRODUCTION}

Sustainability reporting (SR) provides social, environmental, and governance information to enable others to assess how sustainable an organization's operations are. SR practices are also called as Corporate Social Responsibility (CSR) reporting, non-financial reporting, triple bottom line reporting, or value reporting. This new genre of corporate reporting received attention from a wide range of academic study and reporting practices have been explained in various theoretical perspectives, such as the stakeholder theory and agency theory. Such disclosures are significant influences on improving accountability, transparency, and firm performance. The influence of SR on improving firm performance has been widely investigated in prior research.

The aim of this paper is to examine SR and its relation with firm performance. For this purpose, we investigate whether there is a relationship between such reporting practices and the firm performance while enhancing firm value and profitability; and additionally, we analyze the financial leverage impact on SR in the automotive industry. We did logistic regression analysis on panel data of 155 firms from the automotive industry of different countries, between 2010-2018 years, with 1234 firm-year observations. We use the following independent variables such as Tobin's Q ratio for firm value, return on assets for profitability, total assets for the firm size and financial leverage to measure their financial performance, and we work with GRI's reports on GRI Sustainability Disclosure Database as our dependent variable. Tobin's Q that is most suitable for the measure of long-term performance is calculated by dividing the total market value of the firm to total asset value (Sampong, 2018; Laskar, 2018).

In the next section, we provide prior research on the relation between SR and firm performance, and we develop our hypotheses. Subsequently, we provide our data and methodology. Finally, we present the results and give a conclusion. 


\section{PRIOR RESEARCH AND HYPOTHESES DEVELOPMENT}

In the literature, there are many studies, which work SR and firm performance in various theoretical perspectives. According to stakeholder theory, CSR reporting has a positive impact on firm performance, as it improves employee productivity, increases organizational efficiency and enhances the social reputation and product competitiveness (Sampong et al., 2018). Agency theory states that companies use different communication channels to diminish information asymmetry between firms and external agents. CSR reporting is useful in reducing information asymmetries and agency costs and in enhancing firm performance (Karaman et al., 2018).

Bocquet et al. (2017) study the impact of innovation and corporate social responsibility on firm performance. They conduct linear regression analysis on 213 firms and find that firms implementing technological innovation have positive impacts on firm growth. Bradford et al. (2017) work corporate sr and customer concerns with a sample of 15 firms, and they conduct content analysis. Their results show that risk, compliance, and social justice are dimensions of interest to customers, but the economic dimension has not such importance. McGuinness et al. (2017) study the role of board gender and foreign ownership in the CSR performance. They use regression analysis with a sample of 2412 firms between 2009 and 2013, and they find more excellent gender balance in top-management supports stronger CSR performance. Miller et al. (2018) study CSR reputation and firm performance with panel data regression analysis. They find that changes in CSR reputation have predictable, asymmetric, and sizeable impacts on firm performance. Sampong et al. (2018) examine the relationship between CSR disclosure performance and firm value. They use regression analysis with CSR disclosure performance as an independent variable, and Tobin's $Q$ is used as a measure of firm value. They find a positive insignificant relationship between CSR disclosure performance and firm value. Wei et al. (2012) make a conceptual framework study on CSR strategy, green innovation, and firm performance. They conclude that proactive CSR strategy is more positively correlated to short-term firm performance.

Michelon et al. (2014) study CSR reporting practices and the quality of disclosure. They use regression analysis and find CSR reporting practices are not associated with higher disclosure quality. Laskar (2018) emphasize the impact of CSR reporting on firm performance between developed and developing countries of Asia. They use a logistic regression model and find a significant positive relation between SR and firm's performance. The relative impact of SR on firm performance is more in developed countries than in developing countries of Asia. Karaman et al. (2018) are also used as a logistic regression model to find the relationship between GRI-based reporting and firm performance. They mainly focus on the aviation industry, and they emphasize the mainly firm size and financial leverage are positively associated with SR. Although there is not an empirical consensus about the impact of sustainability reporting on firm performance, we aim to find the relationship between firm performance and GRI-based sustainability reports in the automotive industry. We built our hypotheses inspired by the study of Karaman et al. (2018). We test the following hypotheses:

H1. Firms that have superior firm performance in the automotive industry, are more likely to publish sustainability reports

H2. Firms that have higher leverage in the automotive industry, are more likely to publish sustainability reports.

\section{DATA AND METHODOLOGY}

\subsection{Research Design}

We use a logistic regression model that is a particular form of regression, and it is created to anticipate and analyze a binary categorical variable. Logistic regression analysis can have used all types of the independent variables, and their heteroscedasticity is not required. Linear relationships between variables are not required (Hair et al., 2014).

Our logistic regression model is expressed as below:

$$
S D D_{t}=\beta_{0}+\beta_{1} L O G A S S E T S+\beta_{2} R O A+\beta_{3} L E V E R A G E+\beta_{4} T O B I N S Q+\varepsilon
$$

Where SDD represents the inclusion in the GRI Sustainability Disclosure Database. LOGASSETS is the natural log of total assets of a firm (Datastream code: WC03999). Return on Assets (ROA) is the ratio of net income basic (Datastream code: WC01706) to total assets (Datastream code: WC03999); LEVERAGE is the ratio of total debt (Datastream code: WC03255) to total assets (Datastream code: WC03999); and Tobin's Q is the ratio of market value (Datastream code: MV) to total assets (Datastream code: WC03999). Our dependent variable SDD is a categorical variable taking the value of 1 if the company include in GRI Sustainability Disclosure Database ${ }^{1}$ And a value of 0 otherwise. The independent variables are logassets, return on assets, leverage and Tobin's Q ratio.

\subsection{Data}

We used data from two sources; Thomson \& Reuters Datastream Database and GRI Sustainability Disclosure Database. We collect our financial data in Thomson \& Reuters Datastream Database. We use the GRI Sustainability Disclosure Database to determine the dependent variable. Our study concerns 155 automotive firms from 20 different countries in the period of 2010 - 2018; hence, we have 1234 firm-year observations. The number of observations per significant countries is as follows 369 in China, 198 in India, 117 in Japan, 108 in Hong Kong and the US, 99 in Germany, 72 in Thailand, 54 in France and Sweden, 45 in Italy, Korea, Taiwan, and the UK. Furthermore, the percentage distribution of sample firms by region are as follows Africa and Latin America \& The Caribbean 9 (0,6\%), Asia 981 (69\%), Europe 315 (22,2\%), Northern America 108 (7,6\%).

\footnotetext{
${ }^{1}$ https://database.globalreporting.org/
} 
Table 1: Descriptive Statistics of Variables

\begin{tabular}{|l|l|l|l|}
\hline Variable & Obs & Mean & Std. Dev. \\
\hline SDD & 1422 & .185654 & .388964 \\
\hline LOGASSETS & 1367 & 6.382359 & .9794293 \\
\hline ROA & 1367 & .0609377 & .4237434 \\
\hline LEVERAGE & 1365 & .242457 & .1681424 \\
\hline TOBINSQ & 1236 & 1.209538 & 1.781204 \\
\hline
\end{tabular}

In table 1, we give the descriptive statistics of dependent and independent variables used in the logistic regression model. The inclusion in the GRI Sustainability Disclosure Database has 18.56 percent of 1234 firm-year observations with a standard deviation of 0.3889 . The 6.09 percent of all observations have a positive return on assets with a standard deviation of 0.4237 .

Table 2: Correlation of Variables (Obs $=1234)$

\begin{tabular}{|l|l|l|l|l|l|}
\hline & SDD & LOGASSETS & ROA & LEVERAGE & TOBINSQ \\
\hline SDD & 1 & & & & \\
\hline LOGASSETS & 0.1636 & 1 & & & \\
\hline ROA & $-0.0124^{*}$ & $-0.0310^{*}$ & 1 & & \\
\hline LEVERAGE & $0.0232^{*}$ & 0.2143 & $-0.0654^{* *}$ & 1 & \\
\hline TOBINSQ & -0.1005 & -0.3056 & 0.1653 & -0.2748 & 1 \\
\hline * Correlation significant at the $0,05, * *$ Correlation significant at the 0,10 \\
\hline
\end{tabular}

Table 2 shows the correlation between variables of 1234 firm-year observations. The SDD variable has a negative (-1.24\%) correlation with the ROA variable, and positive (2.32\%) with the LEVERAGE variable at the 0.05 significance level. The LOGASSETS variable has a negative ($3.1 \%)$ correlation with the ROA variable with the 0.05 significance level. Between the ROA variable and the LEVERAGE variable, there is a negative $(-6.54 \%)$ correlation at the 0.10 significance level.

\section{FINDINGS}

According to the results of the logistic regression, the model has 18.14 Wald Chi2 value with 1 percent significance level. The results of testing $\mathrm{H} 1$, which predicts that SR will be positively associated with the firm performance in terms of firm size, are presented in Table 3 . They depict a positive and significant relationship between firm size and SR at 1 percent level. These results confirm stakeholder and agency theory, which state CSR reporting has a positive relationship with firm performance in terms of firm size. Otherwise, we cannot find any significant relation between ROA and TOBINSQ with SR in this model.

Table 3: Results of Logistic Regression Analysis

\begin{tabular}{|l|l|}
\hline LOGASSETS & $1.590042(0.000)^{*}$ \\
\hline ROA & $-2.914196(0.154)$ \\
\hline LEVERAGE & $-2.478525(0.075)^{* *}$ \\
\hline TOBINSQ & $0.5740185(0.638)$ \\
\hline _cons & $-13.14973(0.000)^{*}$ \\
\hline Log-likelihood & -410.08157 \\
\hline Wald chi2 & $18.14^{*}$ \\
\hline Prob > chi2 & 0.0012 \\
\hline $\begin{array}{l}* \text { Variable significant at the } 0,01,{ }^{* *} \text { Variable significant at the } 0,10 \\
\text { The final number of observation } 1234 \text {, the final number of firms 155 }\end{array}$ \\
\hline
\end{tabular}

However, the results of the logistic regression testing $\mathrm{H} 2$ report a negative and significant relationship between financial leverage and SR at a 10 percent significance level. In the relevant literature, Sampong et al. (2018) find similar results with our study; they notice a positive insignificant relationship between CSR disclosure performance and firm value. On the other hand, Karaman et al. (2018) obtain adverse results in terms of financial leverage since they report a positive association between financial leverage and SR.

\section{CONCLUSION}

The study examined the impact of SR practices on firm performance. We conducted logistic regression analysis on panel data of 155 firms from the automotive industry of different countries, between 2010-2018 years, with 1234 firm-year observations. We use financial data such as Tobin's $Q$ ratio, total assets, return on assets and financial leverage of the public companies to measure their financial performance, total assets for the firm size and we work with GRI's reports on GRI Sustainability Disclosure Database. First, our findings indicate a positive significant relationship between firm size and SR. Second; we found a negative significant relationship between financial leverage and 
sustainability reporting in the automotive industry. Future studies can search for the relation of SR and firm performance in different sectors. Furthermore, testing different independent variables may contribute to the development of the model. Moreover, hypotheses can be tested by region and nature of the sustainability reports.

\section{Acknowledgment}

This work has been realized with the support of Galatasaray University Scientific Research Fund [grant number: 18.102.003].

\section{REFERENCES}

Bocquet, R., Le Bas, C., Mothe, C., \& Poussing, N. (2017). CSR, Innovation, and Firm Performance in Sluggish Growth Contexts: A Firm-Level Empirical Analysis. Journal of Business Ethics, 146(1), 241-254. DOI: 10.1007/s10551-015-2959-8.

Bradford, M., Earp, J. B., Showalter, D. S., \& Williams, P. F. (2017). Corporate sustainability reporting and stakeholder concerns: Is there a disconnect? Accounting Horizons, 31(1), 83-102. DOI: 10.2308/acch-51639.

Hair Jr., J. F., Black, W. C., Babin, B. J., \& Anderson, R. E. (2014). Multivariate Data Analysis. Seventh Edition. Pearson New International Edition. ISBN 10: 1-292-02190-X.

Karaman, A. S., Kilic, M. \& Uyar, A. (2018). Sustainability reporting in the aviation industry: worldwide evidence, Sustainability Accounting, Management and Policy Journal, 9(4), 362-391, https://doi.org/10.1108/SAMPJ-12-2017-0150.

Laskar, N. (2018). Impact of corporate sustainability reporting on firm performance: an empirical examination in Asia, Journal of Asia Business Studies, 12(4), 571-593, https://doi.org/10.1108/JABS-11-2016-0157.

McGuinness, P. B., Vieito, J. P., \& Wang, M. (2017). The role of board gender and foreign ownership in the CSR performance of Chinese listed firms. Journal of Corporate Finance, 42, 75-99. DOI: 10.1016/j.jcorpfin.2016.11.001.

Michelon, G., Pilonato, S., \& Ricceri, F. (2015). CSR reporting practices and the quality of disclosure: An empirical analysis. Critical Perspectives on Accounting, 33, 59-78. https://doi.org/10.1016/j.cpa.2014.10.003.

Miller, S. R., Eden, L., \& Li, D. (2018). CSR reputation and firm performance: A dynamic approach. Journal of Business Ethics, 1-18, https://doi.org/10.1007/s10551-018-4057-1.

Sampong, F., Song, N., Boahene, K., \& Wadie, K. (2018). Disclosure of CSR Performance and Firm Value: New Evidence from South Africa based on the GRI Guidelines for Sustainability Disclosure. Sustainability. DOI: 10.3390/su10124518.

Wei, J., Peng, X. R., \& Zhang, Y. (2012). CSR strategy, green innovation, and firm performance: A conceptual framework. 2012 International Symposium on Management of Technology, ISMOT 2012, 482-485. DOI: 10.1109/ISMOT.2012.6679519. 